\title{
The Influence of Selected Elements of Schools Culture on Students' Academic Performance in Southwestern Nigeria
}

\author{
B.O. Emunemu \\ Department of Educational Management \\ University of Ibadan, Nigeria \\ Email: doriben7701@yahoo.com \\ E.O. Adu \\ Faculty of Education \\ University of Fort Hare, South Africa \\ Email:eadu@ufh.ac.za \\ and

\section{I.O. Yusufu} \\ Department of Educational Management \\ University of Ibadan, Nigeria \\ Email: toyinyusuf@gmail.com \\ DOI: http://dx.doi.org/10.4314/gjds.v11i1.4
}

\begin{abstract}
This study was conducted on the elements of school culture which are teachers' collaboration, self-efficacy and goal achievement orientation and students' academic performance. The expost facto using descriptive survey design was adopted. Multi-stage sampling technique was used to select the sample for this study. The results revealed that valuing teachers' collaboration contributed significantly to students' academic performance $(\beta=0.468 ; t=8.986 ; p<.05)$, followed by valuing achievement goal orientation which also contributed significantly to students' academic performance $(\beta=0.446 ; t=5.078 ; p<.05)$, while valuing teachers' selfefficiency contributed insignificantly to students' academic performance $\beta=-0.033, t=0.428$; $p>0.05)$. It was recommended among others that secondary school leaders should carry out
\end{abstract}


school culture elements audit test in their schools to know whether teachers understand the concept of school culture and how it relates to their jobs, students and the school, and how they could benefit from training in school culture oriented programmes so as to take advantage of improvement in school culture towards enhancing their students' academic performance.

Key words: Teachers' Collaboration, Self-Efficacy, Achievement Goal Orientation, Secondary School Students, Academic Performance.

\section{Background to the Study}

There is no gainsaying the fact that a sound formal (secondary) education is pivotal to a meaningful development of our youth who are the respective leaders of tomorrow. As a matter of fact the learning and nurturing that occur during these years have a profound impact on each student's opportunities for the future. Indeed, the quality of each student's education at the secondary school level has much to do with the course and quality of his/her life as an adult.

Secondary schools are elaborate, complex mini-societies whose internal organizational structures have a direct impact on the lives of the individuals, and groups of individuals who inhabit them (Lee, Dedrick \& Smith, 1991). In addition to their formal organizational structures, secondary schools are equally inherent cultural entities replete with amazing arrays of artifacts, rituals, and rites of passage all of which impact directly on the manner in which their inhabitants negotiate the terms of their existence within those institutions (Hemmings, $2000 \&$ Hoffman, 2003). The degree of success with which these negotiations are concluded has a significant effect on participants' long-term success, or lack thereof, within those walls (Hemmings, 2000).

Little wonder that education is a major undertaking of governments around the world. It accounts for a substantial proportion of public and private expenditure, averaging around 4 percent of Gross Domestic Product (GDP) in Organization for Economic Cooperation and Development (OECD) countries (OECD, 1994). Hence, in return for this investment, high hopes are held for education as an instrument of social and economic policy for the betterment of individual, community and national well-being, (Hill, Rowe \& HolmesSmith, 1995).

Conventionally, secondary schools' students are expected to vie for a place in any of the tertiary institutions after the completion of their studies, while the standard expectation from them to enter any of the tertiary institutions in the country is " 5 credits" from a minimum of seven (7) subjects to be registered for in any public examinations like West African Examinations Council (WAEC) and National Examination Council (NECO). Expectedly, English Language, being the lingua franca of the country is believed to be so vital because, it is the only recognized mode of instructional communication in the tertiary institutions except for the students in the Language Departments that can apply 
their language of study where necessary. English Language was so much respected that even in some indigenous language departments like Yoruba, Ibo and Hausa Language departments, some Universities still make it mandatory that students' undergraduate project must be written in English Language. A student who is deficient in this subject is assumed unlikely to do well in the academic work - both in oral and written form as expected by the tertiary institution regulations.

Mathematics is equally ranked among the prerequisite subjects because there is no course that will not require a student to do some statistical applications and analysis whether during the course of group work, term-papers writing or when writing their undergraduate project. A student who is deficient in this subject is assumed may not be able to showcase his/her academic work in a simple statistical format which is the internationally recognized mode of presentation. The other three subjects required of any student to enter the tertiary institution of his/her choice depends on the student's course of study, that is whether he/she is pursuing a Science based, Art based or Social science based course.

Adu (2012) established that about 93 percent of secondary school leavers in any given year failed to qualify for university education. Results of 1997 Senior School Certificate Examination (SSCE) released by West African Examinations Council (WAEC) indicated that 6.89 percent had credit in English Language while 7.9 percent had credit in Mathematics; the percentage of passes in both papers in National Examinations Council (NECO) examinations was not also significant.

Considering the above scenario, the extent to which secondary schools have performed in producing students for higher education in Nigeria cannot be said to be satisfactory. This is particularly disturbing when it was realized that one of the broad aims of secondary education as stated in the National Policy of Education (Federal Republic of Nigeria, 2004), is preparation of students for higher education. The enormous importance universally attached to education especially at secondary level has continued to attract a lot of researchers into examining factors influencing secondary schools' effectiveness and students' academic performance. Studies have indicated that the issue of students' academic achievement is directly relevant to the educational process, school administration, and curriculum design and to a functional school system (Englet, Tarrant \& Rozandal, 1993). Ukeje (1995) has argued that we should concern ourselves more with the quality of education provided which had definitely declined. But, Fafunwa (1998) a former Federal Minister of Education, and one of the leading educationist in Nigeria, has consistently held the view that standards in education have not declined, rather the expectations have changed as more people participate in education enterprise as teachers, students, examiners, employers, administrators and parents.

Many researchers such as (Adeyemo, 2005; Aremu, 2004; Adepoju, 2001 \& Alabi, 2000) have established the fact that certain teacher, school and home factors play a part in predicting academic performance of students. However, students' learning gains 
through studies on school variables, students variables or classroom variables, singly or in combination so as to enhance students' academic performance, have not yielded the expected significant results as evidenced in various external examinations on yearly basis.

Due to the fact that some variables earlier studied have not effectively solved the problem of low academic performance, some researchers have argued that some elements of school culture and organizational processes which may improve students' academic performance need to be examined (Akinsola, 2002 \& Maslowski, 2001). Edmonds (1979) \& Creemers (1994) have in their various studies identified factors that reflect a school's culture, like achievement orientation, a shared ideology or mission, cohesion and collaboration among teachers.

From the studies of the researchers highlighted above, it was clear that the researchers explicitly aimed at opening the 'black box', that is culture of the school by studying the relationship between school effectiveness and the so-called process characteristics, which relates to the organizational features and internal functioning of schools. Coincidentally, the school leadership literature has steadily expanded on and refined these observations over the last 20 years. It is now empirically believed that if you want to improve schools, you have to change their cultures and possibly structures.

Lee Ve, (2002) identified nine characteristics of unusually effective schools. The first he mentioned is a productive school climate and culture. More specifically, effective schools are characterized by an orderly environment. According to Lee Ve, an orderly environment is rather associated with interpersonal relationships, than with regulations. As he noted, "discipline derives from 'belonging and participating' rather than 'rules and external control"' (Lee Ve, 2002:9). Other effectiveness-enhancing factors reflect a similar point of view. For instance, 'faculty cohesion, collaboration, consensus, communications and collegiality' were identified as a crucial feature of effective schools. Staff members have to work as a team to ensure a sense of unity and consistency in their relation with students. Furthermore, faculty input in decision-making was identified as an effectivenessenhancing factor. This refers to a more participatory approach of decision-making, which is likely to enhance the commitment of faculty members.

As Lee Ve indicated, the commitment of staff members and the impetus for collaboration and communication has to be directed towards student achievement. Not only do staff members need to be committed to a shared and articulated mission focused on achievement, but also a school-wide emphasis on recognizing positive performance is indispensable. Staff members need to have a problem-solving orientation, a willingness to experiment and actively search for solutions that might overcome obstacles in student learning, especially with respect to low achievers.

The review of Edwards, Greem \& Lyons (1996) revealed similar effectiveness enhancing school characteristics. Of the eleven factors they identified, the 'shared vision and goals', 'learning environment' and 'positive reinforcement' factors bear close resemblance to the aspects Lee Ve identified as 'productive school climate and culture'. A shared vision and 
shared goals reflect a unity of purpose among the teaching staff of a school that is likely to result in a consistency of practice. Furthermore, the coordination of goals is achieved by means of collegiality and collaboration. Therefore, based on previous studies into effective schools, it was concluded that the concept of school culture was rooted in existing effective school research, and therefore offers a clue for further explaining the 'secret' of effective schools.

Collaborative school cultures relate to the beliefs, norms, and values that school members especially the management and the teaching in groups construct and internalize to orientate their personal and professional relationships. It was argued that the norms of individualism and non-interference that have traditionally defined the teacher culture have been shown to weaken teachers' confidence about the efficacy of their own practice (Ashton et al. 1983). Hence, teachers' collaboration is intended to "promote the most effective teaching possible for the greatest number of students" (Pugach \& Johnson 1995). Collaboration is regarded as a way of changing instruction in order to have a positive effect on student learning outcomes such as higher standardized test scores (Certo \& Fox, 2002).

The teacher's belief that he or she possesses the ability to influence student learning and achievement of all students, including those students who may be considered unmotivated and difficult is commonly referred to as teacher self-efficacy. Teachers' selfefficacy which is an element of school culture is equally believed to be positively related to students' academic performance (Akinsola, 2002; Hoy, 2000 \& Bandura, 1997).

It has been argued that in a time of education policy that is based on equipping students with global knowledge as well as meeting high quality, skillful teachers are needed in the classroom to raise students' performance. How teachers view their own classroom capabilities is of equal importance. Studies showed a positive correlation between teachers' perceived self-efficacy and student achievement while teachers' self-efficacy equally has a direct impact on students' achievement in the classroom (Akinsola 2002 \& Hoy 200o). Bandura (1997) reported that the task of creating learning environments conducive to development of cognitive competencies rests heavily on the talents and selfefficacy of teachers.

This researcher's conversation with educators and students around Nigeria and his observations within the school system established, there is a basic culture of schools that transcends ethnic and socio-cultural borders. As Deal (1995) and Maehr \& Fyans (1989) commented, each school also possesses individualized, unique cultural aspects. Schools have distinct personalities, highly unique ceremonies, varying discipline, norms and academic achievement at the apex of community respect. Organizational (school) culture can be a highly powerful force in the school achievement process; given this analysis of culture, and it stands to reason that, as Owens (2004) noted, it may often be the most determinant of the course of change in an organization. 


\section{Statement of the Problem}

There have been incessant complaints and comments from the general public that the standard of education is falling due to poor performance of secondary school students in public examinations like West African Examination Council (WAEC), National Examination Council (NECO) and Joint Admission and Matriculation Board (JAMB) while the quest by many researchers to proffer solutions to the problem have not yielded the expected significant result. Numerous studies have been carried out on the variables enumerated above, while little has been carried out on school culture characteristics and students' academic performance in Southwestern Nigeria.

It is in view of the above that this study was conducted on the elements of school culture, which are teachers' collaboration, self-efficacy and achievement goal orientation and students' academic performance as one of the solutions to the recurring problem of low secondary school students' academic performance in Southwestern Nigeria.

\section{Research Questions}

1. What composite effect, if any, exist between each of the three key elements of school culture - valuing of teachers' collaboration, valuing of achievement goal orientation, and valuing of teachers' self-efficacy in secondary schools and the level of students' academic performance in Southwestern Nigeria?

2. What relative effect, if any, exists between each of the three key elements of school culture - valuing of teachers' collaboration, valuing of achievement goal orientation, and valuing of teachers' self-efficacy in secondary schools and the level of students' academic performance in Southwestern Nigeria?

3. Which of the three key elements of school culture - valuing teachers' collaboration, valuing achievement goal orientation, and valuing teachers' self-efficacy in secondary schools will significantly predict students' academic performance in Southwestern Nigeria?

\section{Literature Review}

\section{Teachers' Collaboration Teacher Collaboration}

Teachers' collaboration is a culturally oriented phenomenon, which relates to the beliefs, norms, and values that school members, especially the management and the teaching group construct and internalize to orientate their personal and professional relationships. This set of qualities and beliefs about teacher collaboration, which concerns both 
relationship patterns and less commonly, foundations of educational practice, is generally referred to as "collaborative cultures."

Collaborative school cultures are extremely powerful, and are accentuated when combined with moral purpose, creative ideas and positive outcomes (Deshpande, Farley \& Webster, 1993). Zimmerman (1998) eloquently expressed this concept. Where the world is heading (or, more accurately, where it needs to head) makes businesses and schools less different than they have been in the past. Both need to be increasingly concerned with moral purpose and good ideas if they are to be successful and sustainable organization. To be successful beyond the very short run, all organizations must incorporate moral purpose, understand complexity science; and respect, build, and draw on new human relationship inside and outside the organization.

According to Denison and Misha (1995), education is an essential ingredient of national development. It is the greatest legacy that any nation can bequeath to her citizens. However, the aims and objectives of education cannot be achieved solely by a group of the school personnel. Therefore, the need for collaborative efforts among different groups of personnel within the school system cannot be over-stressed. More importantly, the human resources such as different groups of personnel within the school setting need to work together to achieve common educational objectives. Also, since students interact with different groups of personnel who have great influence on their lives during the course of schooling the need for collaborative effort and common focus cannot be overemphasized. Yahaya (2003) stressed further that there is a high rate of maladjusted behaviors among students (e.g. cultism, examination malpractice's, drug and sex abuse) and mass failure in

Denison and Misha (1995) stressed further that there is a high rate of maladjusted behaviors among students (for example, cultism, examination malpractice's, drug and sex abuse) and mass failure in some core subjects. All these reflect the need for urgent collaborative efforts among different groups of personnel in Nigerian schools. This is necessary to enhance qualitative education as well as to achieve the aims and objectives of education.

Collaboration has become a twenty-first-century trend. The need in society to think and work together on issues of critical concern has increased. Shifting the emphasis from individual efforts to group works, from independence to community (Zammuto \& Krakower, 1991). In this age of collaboration, the phenomenon is described in a variety of ways: systems, dialogue, creative problem solving and inter-organizational relationships involved in information technology (Senge, 1990).

In education, collaboration is seen as an opportunity for school renewal (National Council for Accreditation of Teacher Education 2000; Council for Exceptional Children) and an opportunity to involve many individuals in complex educational problems. Examples of these problems are: increased student needs as the number of students from diverse backgrounds who demonstrate low or failing test scores grows; diminished resources; 
an explosion of information through technology, creating a more complex learning environment; and standards-based education requiring creative ways of meeting prescribed outcomes while engaging students in meaningful learning experiences.

\section{Achievement Goal Orientation}

The research on achievement goal orientation largely originates from the works of Zammuto and Krakower, 1991. Their theorizing was grounded on a constructive criticism of the prevailing motivational theories, and the empirical evidence to support their arguments came from re-interpretations of prior research on need achievement, test anxiety, social learning and learned helplessness. They defined achievement motivation as the pursuit of goals relating to increases in competence and judgments of competence.

Although they were not explicit in defining the concept of goal, they both described achievement goals in terms of the purposes for which individuals engage in achievement behaviour. Moreover, they considered achievement goals as something individuals adopt in achievement situations. Achievement goal orientation refers to a somewhat stable, intrinsic factor that influences one's approach to goal achievement

In their work, the key issue was how individuals define success in achievement situations. Based on his work on ability conceptions, they argued that individuals can define success either in a self-referenced fashion for example, in terms of learning something new or performing better than before or based on normative comparison for example, doing better than others. Thus, when individuals seek to increase competence in the former sense, they are said to be task-involved, and when they seek to demonstrate competence in the latter sense, they are said to be ego-involved. These particular goal states were assumed to be elicited in part as a function of the situational setting (for example, competitive vs. individualized task instruction) and differentially to influence further task choice and attainment level.

Although Zammuto and Krakower (1991) were very explicit in defining actualized motivation in terms of situationally induced goal states that is, task-involvement vs. ego-involvement), his own empirical work focused mainly on individual differences in generalized goal tendencies, or, what he called, motivational orientations. They argued that while task - and ego-involvement refer to two situationally induced conceptions of success, task and ego orientations reflect individual differences in the commitment to those criteria of success. These orientations were then to be associated with individuals' perceived causes of success, approaches to studying, and to other educationally relevant outcomes such as the role and valuing of schooling.

\section{School Culture}

The field of education lacks a clear and consistent definition of the concept of school culture. Historically, as far back as 1932, Waller noted that "schools have a culture that is definitely their own", he went on to describe the rituals of personal relationships, the 
folkways, mores, irrational sanctions, moral codes, games, ceremonies, traditions, and laws that were so very similar in many schools and which define what happens in schools. This perspective of a shared culture among schools has been commented on by many observers of the sociology of schools, including (Sarason, 1996).

School culture is defined in the frame of the organizational culture, which Schein (1992:12) defines as: "A pattern of shared basic assumptions that the group learned as it solved its problems of external adaptation and internal integration, that has worked well enough to be considered valid and, therefore, to be taught to new members as the correct way to perceive, think, and feel in relation to those problems." Deal \& Kennedy (1983) popularized Bower's definition of organizational culture as "the way we do things around here". Organizational culture embodies organizational beliefs, feelings, behaviours and symbols. In essence, organizational culture entails shared philosophies, ideologies, beliefs, feelings, assumptions, expectations, attitudes, norms and values. When organizational members communicate with one another they speak a common language, use similar terminology and observe similar rituals and ceremonies. Standards of behaviours evolve in the workplace, as group norms result in benchmarks and standards. Typical examples of dominant organizational values in schools include high performance expectations of teachers and students, low absentee and drop-out rates and a high degree of efficiency.

Schools articulate their philosophy through vision and mission statements (Bolman \& Deal, 2003). Creating an organizational culture is a complex process. Key players include organizational heroes and heroines, rites, rituals and communication networks. Heroes and heroines immortalize the school's underlying values, provide role models, symbolize the school to outsiders and establish performance standards to motivate teachers and students to reach high performance outcomes. Everyday activities and celebrations that characterize the school may include teacher of the year, appointing a new principal, graduations, awards banquets or ceremonies. Stories or myths depicting heroes and heroines are communicated through a communications network.

\section{Teachers' Self-efficacy}

The teacher's belief that he or she possesses the ability to influence student learning and achievement for all students, including those students who may be considered unmotivated and difficult is commonly referred to as teacher self-efficacy (Akinsola, 2008; Hoy, 2000; Bandura, 1997 \& Guskey, 1987).

In 1977, the Rand Corporation studied planned change over a period of four years. The "Change Agent Study" looked closely at the change process and teacher growth. It was found that teacher efficacy was the most significant teacher attribute to growth and change throughout these studies (Rand, 1977, No VII). However, teacher efficacy was considered in a broad sense that combined beliefs about teachers in general with beliefs about individual ability. Research by McLaughlin \& Marsh (1978) found teacher efficacy 
to positively impact: achievement of a project goal; the amount of adjustment made by the teacher throughout the project; student achievement; and continued use of project methods and materials (Smylie, 1990). Over the last twenty years, the construct of teacher efficacy has evolved from Albert Bandura's (1997) social cognitive theory. However, the meaning and measure of teacher efficacy has been the subject of considerable debate among scholars and researchers (Gibson \& Dembo, 1984).

In a time of reform that is based on equipping students with global knowledge as well as meeting pre-established bureaucratic standards, high-quality skillful teachers are needed in the classrooms to raise student achievement. How teachers view their own classroom capabilities is of equal importance. Studies show a positive correlation between teachers' perceived self-efficacy and student achievement (Akinsola, 2008; Hoy, 2000; Bandura, 1997 \& Smylie, 1990), teachers who are supported by skillful principal leaders display a better sense of teacher efficacy than those who do not have principal support.

According to the study carried out by Brookover, Beady, Flood Schweitzer \& Wisenbaker. (1978) on social-psychological variables that set schools of similar socio-economic standards and racial composition apart, based on students' academic performance, it was found out that teachers who demonstrate a great instructional commitment to students and practise positive reinforcement, nurture higher-achieving students. The Brophy \& Evertson study of 1977 revealed students of teachers with high student expectations and strong feelings of responsibility to the students made higher academic gains (Brophy \& Evertson, 1977).

\section{Research Methodology}

\section{Research Design}

This study was conducted ex-post facto using the descriptive survey design to investigate the relationship among teachers' collaboration, self-efficacy and achievement goal orientation on performance of secondary school students' in Southwestern Nigeria. The study population comprised principals and teachers on one hand and the students on the other hand in all public and private secondary schools in Southwestern Nigeria.

\section{Sample and Sampling Technique}

Multi-stage sampling technique was used to select the sample for this study. Firstly, a stratified sampling was used to select States from the Southwestern Nigeria geopolitical zone. Secondly, stratified random sampling technique was used to select Local Government Areas via Senatorial Districts. Thirdly, purposive random sampling was used to select the schools from the local government areas. Disproportionate random sampling technique was used in sampling the teachers and students from the schools. 


\section{Research Instruments}

The research instruments used in collecting primary data for this study were:

1. School Culture Questionnaire (SCQ) for Principals and Teachers.

2. Achievement Test for Students in the following subjects:

1. English Language

2. Mathematics

3. Biology

4. Economics

5. Government.

\section{Validation of the Instrument}

The validity of the instrument was done by sending copies of the questionnaires drafts to my supervisor (both internal and external), education experts, principals and teachers, colleagues with a covering letter indicating the purpose of the study, the research questions as well as research hypothesis to be tested. Modification(s) were done on the questionnaires based on the suggestions and comments made by the experts.

\section{Reliability of the Instrument}

The scores obtained from the responses of the respondents to the questionnaires used for pre-study were subjected to a reliability test. To test stability and reliability of the instruments in this study, split-half method was used. The correlation of the whole test was carried out using Cronbach alpha formula which resulted in the reliability co-efficient of 0.93 which was regarded as okay. The achievement test reliability was measured. The correlation of all the Achievement Test Questionnaire (ATQ) tests were carried out using the Kudar Richardson 20 formula which resulted in the reliability co-efficient of 0.74 for Economics, 0.81 for English Language, 0.86 for Mathematics, 0.69 for Biology and 0.66 for Government respectively which was regarded as okay.

\section{Data Analysis and Discussion}

\section{Demographic Statistics of the Students}

A total number of 3416 males and 4489 female students were used which constituted 42.17 percent and 55.40 percent respectively of the sampled population, while 197 or 2.43 percent did not indicate their gender on the ATQ. Also, students from Oyo State, Ondo 
State and Lagos State were 4,374 (42.89\%), 1,946 (24.02\%) and 2,680 (33.09\%) respectively as shown in the table one:

Table 1: Students' Demographic Statistics

\begin{tabular}{|l|l|l|l|}
\hline Variable & Frequency & $\%$ & Cumulative \% \\
\hline Gender: Male & 3416 & 42.17 & 42.17 \\
Female & 4487 & 55.40 & 97.57 \\
Not indicated & 197 & 2.43 & 100.00 \\
Total & $\mathbf{8 1 0 0}$ & $\mathbf{1 0 0 . 0 0}$ & $\mathbf{1 0 0 . 0 0}$ \\
\hline State: Oyo & 4374 & 42.89 & 42.89 \\
Ondo & 1946 & 24.02 & 66.91 \\
Lagos & 2680 & 33.09 & 100.0 \\
\hline Total & 8100 & 100.00 & 100.00 \\
\hline
\end{tabular}

\section{Teachers' Demographic Statistics}

A total number of 657 teachers were sampled from Oyo State, 452 teachers from Ondo State and 503 teachers from Lagos State for the study. In the age bracket, 895(55.52\%) teachers fall below 40 years of age while 588 (36.48\%) teachers or were above 40 years of age and $129(8.0 \%)$ teachers or did not indicate their age in the Questionnaire.

The demographic statistics showed that 623 (38.65\%) teachers were male while 855 (53.04\%) teachers were female and 134 teachers or $8.31 \%$ did not indicate their sex in the appropriate column of the Questionnaire as shown in the table.

Four hundred and twenty one teachers or $26.12 \%$ possessed Master's Degree and above as their educational qualification, 700 (43.42\%) teachers possessed Bachelor's Degree in Education or its equivalent like Bachelor of Science or Bachelor of Art, 321 (19.91\%) teachers possessed National Certificate of Education while 129 (9.0\%) teachers did not indicate their educational qualification at the appropriate column of the questionnaire as shown in the table two:

A total sum of $754(46.77 \%)$ teachers had over five years teaching experience, 774 (48.01\%) teachers had between 3-5 years, while 61(3.78\%) teachers had below three years teaching experience and 23 teachers omitted this column when completing the questionnaire as shown in table two. 
Table 2: Teachers' Demographic Statistics

\begin{tabular}{|l|l|l|l|}
\hline Variable & Frequency & $\%$ & Cumulative \% \\
\hline State: Oyo & 657 & 40.76 & 40.76 \\
Ondo & 452 & 28.04 & 68.80 \\
Lagos & 503 & 31.20 & 100.00 \\
Total & $\mathbf{1 6 1 2}$ & $\mathbf{1 0 0 . 0 0}$ & $\mathbf{1 0 0 . 0 0}$ \\
\hline Age: Below 40 & 895 & 55.52 & 55.52 \\
Above 40 & 588 & 36.48 & 92.00 \\
Not indicated & 129 & 8.00 & 100.0 \\
Total & $\mathbf{1 6 1 2}$ & $\mathbf{1 0 0 . 0 0}$ & $\mathbf{1 0 0 . 0 0}$ \\
\hline Gender: Male & 623 & 38.65 & 38.65 \\
Female & 855 & 53.04 & 91.69 \\
Not indicated & 134 & 8.31 & 100.00 \\
Total & $\mathbf{1 6 1 2}$ & $\mathbf{1 0 0 . 0 0}$ & $\mathbf{1 0 0 . 0 0}$ \\
& 421 & 26.12 & \\
Professional Qualification: B.Sc.\& above & 700 & 43.42 & 26.12 \\
B. Ed. & 321 & 19.91 & 69.54 \\
NCE & 41 & 2.54 & 89.45 \\
Others & 129 & 0.00 & 91.99 \\
Not indicated & $\mathbf{1 6 1 2}$ & $\mathbf{9 9 . 9 9}$ & 99.99 \\
Total & 754 & $\mathbf{9 9 . 9 9}$ \\
\hline Teaching Experience: Above 5years & 774 & 46.77 & 46.77 \\
3-5years & 61 & 48.01 & 94.78 \\
Below 3years & 23 & 3.78 & 98.56 \\
Not indicated & 1612 & 1.43 & 99.99 \\
\hline Total & & 99.99 & 99.99 \\
\hline
\end{tabular}

\section{Research Question 1:}

What composite effect, if any, exist between the three key elements of school culture valuing teachers' collaboration, valuing achievement goal orientation, and valuing teachers' self efficacy in secondary schools and students' academic performance in Southwestern Nigeria?

Table 3a: Composite effect of the three variables on the students' academic performance.

\begin{tabular}{|l|l|l|l|l|}
\hline Model & $\mathrm{R}$ & $\mathrm{R}^{2}$ & $\begin{array}{l}\text { Adjusted } \\
\mathrm{R}^{2}\end{array}$ & Standard Error \\
\hline 1 & .133 & .018 & .017 & 7.71 \\
\hline
\end{tabular}

Table za reveals that 1.7 percent of total variance of students' academic performance was accounted for by the three variables (Adjusted $\mathrm{R}^{2}=0.017$ ). 
Table $3 b$ : Significant status of the composite effect of the three variables on the students' academic performance

\begin{tabular}{|c|c|c|c|c|c|}
\hline Model & $\begin{array}{l}\text { Sum of } \\
\text { Squares }\end{array}$ & Df & Mean Square & $\mathrm{F}$ & Sig \\
\hline $\begin{array}{l}1 \text { Regression } \\
\text { Residual } \\
\text { Total }\end{array}$ & $\begin{array}{l}1328.770 \\
89781.016 \\
91108.786\end{array}$ & $\begin{array}{l}3 \\
1511 \\
1514\end{array}$ & $\begin{array}{l}442.923 \\
59.418\end{array}$ & 7.454 & 0.00 \\
\hline
\end{tabular}

Table $3 b$ revealed that the composite effect of the three key variables on students' academic performance is significant $\mathrm{F}\left(3_{1511)} \nabla 7.454 ; \mathrm{P}<.05\right)$. Hence, there is a significant composite effect of the three key variables on students' academic performance. This finding is in conformity with the findings of Ezeike (1994), but this finding is in contrast with the findings of Maslowski (2001) which established that there was no significant composite effect between some elements of school culture and students' academic performance.

\section{Research Question 2:}

What relative effect, if any, exist between each of the three key elements of school culture - valuing of teachers' collaboration, valuing of achievement goal orientation, and valuing of teachers' self efficacy in secondary schools and the level of students' academic performance in Southwestern Nigeria?

Table 4: Relative effect of the three key variables on students' academic performance

\begin{tabular}{|l|l|l|l|l|l|l|}
\hline & \multicolumn{2}{|l|}{$\begin{array}{l}\text { Unstandardized } \\
\text { Co-efficient } \\
\text { Model }\end{array}$} & Beta B & Rate & t & Sig. \\
\hline 1 (Constant) & & & & & & \\
Valuing teachers' & 49.670 & 0.433 & 0.468 & 1 st & 114.709 & .000 \\
collaboration & -0.213 & 0.024 & 0.446 & 2nd & 8.986 & .000 \\
Valuing students' & 0.249 & 0.049 & -0.033 & 3 rd & 5.078 & .000 \\
achievement goal & $-2.03 E-02$ & 0.047 & & & -0.428 & .669 \\
$\begin{array}{l}\text { Orientation } \\
\text { Valuing teachers' self- } \\
\text { efficacy }\end{array}$ & & & & & & \\
\hline
\end{tabular}

Table 4 revealed that valuing teachers' collaboration contributed significantly to students' academic performance $(\beta=0.468 ; t=8.986 ; p<.05)$, followed by valuing achievement goal orientation, which also contributed significantly to students' academic performance $(\beta=$ $0.446 ; \mathrm{t}=5.078 ; \mathrm{p}<.05)$, while valuing teachers' self-efficiency contributed insignificantly to students' academic performance $(\beta=-0.033, t=0.428 ; p>0.05)$. 
This implied that in this study, valuing teachers' collaboration and valuing achievement goal orientation have relative effect on students' academic performance. This finding corroborated the findings of (Akinsola, 2008; O'Neil \& Conzemius, 2002; Goddard, 2002 \& Goodlad, 1975) with respect to valuing teachers' collaboration and student academic performance; and the findings of Ezeike (1994) with respect to valuing achievement goal orientation and student academic performance.

\section{Research Question 3:}

Which of the three key elements of school culture - valuing of teachers' collaboration, valuing of achievement goal orientation, and valuing of teachers' self-efficacy in secondary schools significantly predict students' academic performance in secondary schools in Southwestern Nigeria?

According to Table 4, only two out of the three variables examined could predict the students' academic performance. These are, valuing of teachers' collaboration and valuing of achievement goal orientation.

The prediction equation could be presented thus: $\mathrm{Y}=\mathrm{C}-\mathrm{X}_{1}+\mathrm{X}_{2}$

Where: $\mathrm{Y}=$ student academic performance

$C=$ constant

$\mathrm{X}_{1}=$ valuing of teachers' collaboration

$\mathrm{X}_{2}=$ valuing of achievement goal orientation

Hence, we have student academic performance $=49.670-0.213 \mathrm{X}_{1}+0.249 \mathrm{X}_{2}$

\section{Conclusion}

The study showed that there was a significant composite effect of the three key variables on students' academic performance, F $\left(3_{1511)} \otimes 7.454 ; \mathrm{P}<.05\right)$. Also, in this study, only valuing teachers' collaboration $(\beta=0.468 ; t=8.986 ; p<.05)$, and valuing achievement goal orientation $(\beta=0.446 ; t=5.078 ; p<.05)$, have relative effect on students' academic performance. The study also revealed that there is a positive significant relationship between valuing goal achievement orientation and students' academic performance ( $r$ $=0.36 ; \mathrm{P}<.05)$; valuing teachers' collaboration and students' academic performance $(\mathrm{r}=$ $0.069, \mathrm{p}<.05)$; and valuing teachers' self efficacy and students' academic performance $(\mathrm{r}$ $=0.038 ; \mathrm{P}<.05)$. It was equally revealed that valuing of teachers' collaboration predicted students' academic performance the most, $(\beta=-0.412 ; t=-4.329 ; \mathrm{p}<.05)$, followed by valuing achievement goal orientation predicted students' academic performance, $\beta=$ 
0.478; $\mathrm{t}=2.953 ; \mathrm{p}<.05)$, while valuing teachers' self efficacy predicted students' academic performance the least, $(\beta=0.122, t=0.877 ; p>7.05)$.

The implication of the finding is that some elements of school culture like teachers' collaboration, teachers' self efficacy and students' orientation to goal orientation in our secondary school need to be improved upon or introduced so as to assist in improving the students' academic performance in our secondary schools.

The results from the analysis of the data using descriptive and inferential statistic like multiple regression analysis showed that some elements of school culture like teachers' collaboration, teachers' self-efficacy and achievement goal orientation correlate with the students' academic performance in secondary schools in Southwestern Nigeria. Thus, analyzing how some elements of school culture correlate with the students' academic performance has significant theoretical and practical implications for administrative and instructional decision-making and practices. If educators and administrators wish to improve the academic experience of secondary school students, understanding these school cultural factors, which enhance or undermine performance, should be of primary concern in Southwestern Nigeria secondary schools.

\section{Recommendations}

In view of the fact that there is need to find further ways of improving the students' academic performance in Southwestern Nigeria, it is recommended that secondary school leaders should carry out school culture elements audit test in their schools to know whether its teachers understand the concept of school culture and how it relates to their jobs, students and the school, and how they could benefit from training in school culture - oriented programmes so as to take advantage of improvement in school culture towards enhancing their students' academic performance.

The leaders can be proactive in strengthening cherished norms and traditions, and in bringing about intentional change in the interests of maintaining or creating through a process of re-culturing or "normative re-education" (Stoll \& Fink, 1996), a 'strong' culture conducive to continuous improvement and long-term institutional success.

The Ministry of Education in Nigeria should formulate secondary school culture policy which will guide and mandate secondary schools' principals to inculcate the habit of forming mission statement for their schools which will guide the culture of the school. Teacher training institutions in the country should lay emphasis on imparting information to teachers under training regarding organizational culture vis-a-vis school culture; while newly promoted school-heads/principals should be given a short refresher course in school organizational culture. 


\section{References}

Adepoju, T. L. (2001). Locational factors as correlates of private cost and academic performance of secondary school students in Oyo State, Nigeria. Unpublished PhD Thesis, University of Ibadan, Department of Educational Management.

Adeyemo, D.A. (2005). Parental Involvement Interest in Schooling and School Environment as predictors of Academic Self-efficacy among fresh Secondary School Student in Oyo State, Nigeria. Electronic Journal of Research in Educational Psychology, 5-3 (1) pp. 163-18o.

Adu, E. O. (2012). Two Problem Based Learning Strategies for Teaching Economics. LAMBERT Academic Publishing.

Akinsola, M.K. (2008). Relationship of some psychological variables in predicting problem solving ability of in-service mathematics teachers. The Montana Mathematics Enthusiast, ISSN 1551-3440, Vol. 5, no.1, pp. 79-100 2008.

Akinsola, M.K. (2002). In-service elementary teachers' mathematics anxiety its relationship to teachers' attitude towards the studying and teaching of mathematics. Nigerian Journal of Applied Psychology, 7(1), pp.188-202.

Alabi, 0. A. (2000). School size, facility utilization and educational opportunities as correlates of students' performance in public secondary schools in Oyo State, Nigeria. Unpublished PhD Thesis, University of Ibadan, Department of Educational Management.

Aremu, A .0. (2004). Psychological and Sociological determinant of academic achievement of Nigeria adolescents. Ife Psychology. An international Journal of Psychology in Africa, 12 , (2), pp.149-161.

Ashton, P. T. \& Webb, R. B. (1986). Teachers' sense of efficacy, classroom behaviour, and student achievement. In P.T. Ashton and R. B. Webb (Eds.). Teachers' Sense of Efficacy and Student Achievement (pp. 125-144). New York: Longman.

Ashton, P.T., Webb, R.B., \& Dodo, C. (1983). A study of teachers' sense of efficacy (final report, Executive Summary. Gainesville: University of Florida.

Bandura, A. (1997). Perceived self-efficacy in cognitive development and functioning. Educational Psychologist, 28, pp.117-148.

Brophy, J. E., \& Evertson, C. (1977). Teacher behaviours and student learning in second and third grades. In G. D. Borich (Ed.) The appraisal of teaching: Concepts and process, pp. 79 - 95. Reading, MA: Addison-Wesley. 
Bolman, L. G., \& Deal, T. E. (2003). Reframing organizations: Artistry, choice, and leadership. San Francisco, CA: Jossey-Bass.

Brookover, W., Beady, C., Flood, P., Schweitzer, J., \& Wisenbaker, J. (1978). School Social Systems and Student Achievement: Schools Can Make a Difference. New York: Praeger.

Certo, J. L. \& Fox, J. E. (2002). Retaining quality teachers. High School Journal, 86(1), pp. 57-75.

Cheng, Y. C. (1993).Profiles of organizational cultures and effective schools. School Effectiveness and School Improvement, 4(2), pp. 85-110.

Creemers, B.P.M. (1994). The history, value and purpose of school effectiveness studies. In: D. Reynolds, B.P.M. Creemers, P.S. Nesselrodt, E.C. Schaffer, S.Stringfield \& Ch. Teddlie (Eds.), Advances in school effectiveness research and practice, pp. 9-23. Oxford: Pergamon.

Deal, T.E. (1995). Symbols and Symbolic Activity. In S.B. Bacharach \& B. Mundell (Eds.)108 - 136. Thousand Oaks, CA: Corwin Press.

Deal, T.E., \& Kennedy, A.A. (1983). Culture and School Performance Educational Leadership, 40 (5), pp. 14-15.

Denison, D.R., \& Mishra, A.K. (1995). Toward a Theory of Organizational Culture and Effectiveness. Organization Science, 6 (2), pp. 204-223.

Deshpande, R., Farley, J. U., \& Webster, F. E. (1993). Corporate culture, customer orientation and innovativeness in Japanese firms: A quadrad analysis. Journal Marketing, pp. $23-27$.

Edmonds, R.R. (1979). Effective schools for the urban poor. Educational Leadership, 37, pp. $15-27$.

Edwards, J.L., Green, K.E., \& Lyons, Ch.A. (1996). Factor and Rasch Analysis of the School Culture Survey. Paper presented at the Annual Meeting of the American Educational Research Association, April 1996, New York.

Englert, C. S., Tarrant, K. L., \& Rozendal, M. S. (1993). Educational innovations: Achieving curricular change through collaboration. Education and Treatment of Children, 16, pp. 441-473.

Ezeike, A. O. (1994). Motivation and Learning. Journal of Educational Development, Vol. 4(5), pp. 34-39.

Fafunwa, A. B. (1998). Memoirs of a Nigerian Minister of Education. Lagos: Macmillan Nigeria. 
Federal Ministry of Education. (2007). Statistics of Education in Nigeria: 2001-2005. Abuja: Statistics \& NEMIS Branch.

Gibson, S. \& Dembo, M. (1984). Teacher efficacy: A construct validation. Journal of Educational Psychology, 76(4), 569-82.

Goddard, R. (2002). A theoretical and empirical analysis of the measurement of collective efficacy: The development of a short form. Educational and Psychological Measurement, 62, (1), 97-110.

Goodlad, J. (1975). The Dynamics of Educational Change. New York: McGraw Hill.

Gruenert, S. (2000). Shaping a new school culture. Contemporary Education, 71, (2), 14.

Guskey, T.R. (1987). Context variables that affect measures of teacher efficacy. Journal of Educational Research, 81, 41-47.

Hemmings, A. (2000). The "hidden" corridor curriculum. High School Journal, 83(2), 1-10.

Hill, P., Rowe, K. \& Holmes-Smith, P. (1995). Factors Affecting Students' Educational Progress: Multilevel modeling of Educational Effectiveness. Paper presented at the 8th ICSIE, Leeuwarden. Netherlands.

Hoffman, L.M. (2003). Why high schools don't change: What students and their yearbooks tell us. The High School Journal, 86(2), 22-38.

Hoy, A. W. (2000), Changes in teacher efficacy during the early years of teaching. Paper presented at the Annual Meeting of the American Educational Research Association, New Orleans, LA.

Lee, V.E. (2002). School size and the organization of secondary schools. In Hallinan, M. T. (Ed.). Handbook of the sociology of education. New York: Kluwer.

Lee, V. E., Dedrick, R. F., \& Smith, J. B. (1991). The effect of the social organization of schools on teachers' efficacy and satisfaction. Sociology of Education, 64(3), 190208.

Maehr, M.L., \& Fyans, L.J. Jr. (1989). School Culture, Motivation, and Achievement. In M.L. Maehr \& C. Ames (Eds.), Advances in motivation and achievement: a research manual, pp. 215-247. Greenwich, CT: JAI Press.

Maslowski, R. (2001). School Culture and School Performance. Unpublished Doctorate thesis, University of Twente, Faculty of Educational Science and Technology, Enschede, The Netherlands.

McLaughlin, M. W. \& Marsh, D. (1978). Staff development and school change. Teachers College Record, 8o(1), 70-94. 
O’ Neil, J.A. \& Conzenius, A. (2002). Four keys to a smooth flight. Journal of Staff Development, 23, (2), 14-18.

Organization for Economic Cooperation and Development (2003). Studentengagement at school: A sense of belonging and participation. Paris: O.E.C.D.

Owens, R.G. (2004). Organizational Behaviour in Education: Adaptive Leadership and

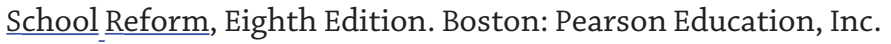

Sarason, S. (1996). Revisiting the culture of school and the problem of change. New York: Teachers College Press.

Schein, E. H. (1992). Organisational culture and leadership. Jossey Bass: Wiley

Senge, P.M. (1990). The Fifth Discipline. New York: Doubleday Currency.

Smylie, M.A. (1990). Teacher efficacy at work. In P. Reyes (Ed.), Teachers and Their Workplace, pp. 48-66. Newbury Park: Sage.

Stoll, L., \& Fink, D. (1996). Changing Our Schools: Linking School Effectiveness and School Improvement. Buckingham: Open University Press.

Ukeje, B.o. (1995). Crisis in the Nigerian Education System. A Keynote address at the Nigeria Academy of Education Congress in November at Abuja.

Zammuto, R.F., \& Krakower, J.Y. (1991). Quantitative and qualitative studies of organizational culture. Research in Organizational Change and Development, 5, 83114 .

Zimmerman, B. J. (1998). Academic studying and the development of personal skill. A self-regulatory perspective. Educational Psychologist, 33, 73-86. 